\title{
MORPHOLOGICAL, PHYSIOLOGICAL AND BIOCHEMICAL GENETIC STUDIES ON SOME INDIAN JUJUBE (ZIZIPHUS MAURITIANA LAMK.) VARIETIES GROWN AT EL NUBARIA
}

\author{
EZZ, THANAA M. ${ }^{1}$, AFAF M. YOUSIF ${ }^{2}$ AND MOHAMED E. FARAG ${ }^{2}$
}

1. Plant Production Department, Fac. of Agric., Saba-Basha, Alex. Univ.

2. Horticulture Research Institute, ARC,Giza

(Manuscript received 18 September 2011)

\begin{abstract}
The present study was conducted in a private orchard during 2007 and 2008 seasons in order to evaluate the morphological, physiological characteristics and molecular marker in the two Indian jujube varieties, Balahy and Tofahy. The results showed that: Tofahy variety recorded the higher vigorous growth, leaf area, leaf length, leaf width and length of primary and secondary shoots, while Balahy variety recorded the higher leaf length/width ratio. Tofahy variety recorded the higher fruit set, fruit number/tree, fruit weight, yield, fruit width, fruit pulp thickness while Balahy variety recorded the higher fruit length, fruit length/width ratio, fruit firmness, seed weight and seed/fruit weight ratio. Tofahy variety recorded the higher fruit acidity, ascorbic acid while Balahy variety recorded the higher leaf and fruit total chlorophyll, fruit TSS/acidity ratio. Tofahy variety recorded the higher leaf and fruit nitrogen, phosphorus, calcium, magnesium, iron, manganese and zinc, leaf potassium and fruit sodium while, Balahy variety recorded the higher fruit potassium. No significant differences were recorded between both varieties concerning fruit drop, volume, TSS, reducing, non-reducing and total sugars, juice $\mathrm{pH}$, chlorophyll $\mathrm{A}, \mathrm{B}$, carotene and leaf sodium. Genetic similarity was found for the two varieties in elecrophoresis analysis, but there were, little differences at the sequence of amino acids in protein and DNA bands.
\end{abstract}

\section{INTRODUCTION}

Ber or the Indian jujube belongs to the family Rhamnaceae that consists of about 45 genera and 550 species. It is widely distributed in tropical and sub-tropical climates in the world. Ber can be successfully cultivated even in the most marginal lands with few agriculture inputs and little attention. The Indian jujube has various names in different languages of the world there are, in Arabic, Aunnabe Hindi, Nabig, Sidr, while, in English, ber, Chinese Date, Indian Cherry, Indian Jujube, Indian Date, Indian Plum. The Indian jujube tree is a vigorous grown and has a rapidly developing tap root system within a short period and it can also withstand alkalinity and slightly water-logged condition. Ber tree may be a bushy shrub, or a tree, erect or wide spreading, with gracefully drooping branches and downy, zigzag branchlets, thornless or set with short, sharp straight or hooked spines (Morton, 1987). This quick growing 
tree starts producing fruits within three years. It will not set fruit by self -pollination, because in the ber varieties both self and cross incompatibility has been reported by Pareek (1983). The fruits are drupe, globose to ovoid, up to $6 \times 4 \mathrm{~cm}$ in cultivation, usually much smaller when wild, skin smooth or rough, glossy, thin but tough, yellowish to reddish, flesh white, crisp, juicy, subacid to sweet, becoming mealy in fully ripe fruits. The average yield of this tree for the different varieties during the prime bearing age of about 10 to 20 years ranged between 80 to $200 \mathrm{Kg}$ fruits per tree (Pareek, 1983). The different part of Indian jujube trees are used in different uses. The leaves and twigs of most species can be used as nutritious fodder for livestock, due to the high dry weight protein content (Ngwa and Mafeni, 2000). The ber tree also, can be used in medicinal uses as well as, the fruits are applied on cuts of ulcers, are employed in pulmonary ailments and fevers indigestion and biliousness. The dried ripe fruit is a mild laxative. They check diarrhea and are poultice on wounds. The leaves are helpful in liver troubles, asthma and fever. Juice of the root bark are used to alleviate gout and rheumatism. An infusion the flowers serve as an eye lotion (Morton, 1987). New plant varieties can now get protection in many more countries. With the ability of getting highly specific, DNA fingerprinting will provide an objective evaluation of genetic identity of plants based on species, cultivars or geographic origin. DNA fingerprint can prove that a new variety satisfies necessary criteria for granting protection. These criteria may include novelty, distinctiveness, uniformity and stability. For administrators of plant property rights, DNA fingerprinting can help in selecting most suitable reference varieties for morphological comparison and save cost. It is most effective in enforcing protection by proving infringement of property rights.

\section{MATERIALS AND METHODS}

The present investigation was conducted during 2007 and 2008 successive seasons in a private orchard (Nubaseed company farm) on the two Indian jujube (Ziziphus mauritiana Lamk ) varieties namely, Balahy and Tofahy. The selected trees were twelve years old of uniform size, planted at $5 \times 5$ meters apart in sandy soil, grafting on Ziziphus spina christi rootstocks. Thirty trees (fifteen trees from each variety) were randomly selected. Five replicates and three trees for each replicate for each variety were used in this study. Experimental trees were arranged in complete block design randomized statistical analysis was carried out using LSD according to Snedecor (1980). 


\section{The following parameters were recorded}

\section{1- Morphological characteristics}

1- During October, a sample of ten mature leaves were chosen, leaf area, length and width were recorded and leaf length/width ratios were calculated.

2- In January, tree height and length of primary and secondary shoots were recorded by graduated tape.

\section{2- Fruit set and drop percentages}

1- To study the fruit set $\%$, number of flowers were chosen in four branches around each tree in August, then after one month the fruit set percentages were determined according to the following equation:

$$
\text { Fruit set } \%=\frac{\text { No. of developingfruitlets }}{\text { No. of flowers at full bloom }} \times 100
$$

3- To study the fruit drop percentages remainder fruits were calculated in October through the following equation:

4-

Fruit drop $\%=\frac{\text { No. of developedfruitlets }- \text { No. of remained fruit }}{\text { No. of developedfruitlets }} \times 100$

\section{3- Yield}

Average fruit weight was determined by weighting the fruit sample (10 fruits) and average weight per fruit was calculated. Moreover, number of fruits per tree was calculated and total yield was determined as follows:

Total yield $(\mathrm{Kg} /$ tree $)=$ No. of fruits tree $\times$ average fruit weight.

\section{4- Fruit characteristics}

A sample of 10 mature fruits were taken during December from each tree to determine the physical and chemical characteristics

\section{Physical fruit characters}

- Fruit length and width $(\mathrm{cm})$ were measured by the calliper, fruit length/width ratio were also calculated.

- Fruit volume was measured via water displacement by using graduated cylinder.

- Fruit firmness was measured by hand fruit pressure tester.

- Fruit pulp thickness $(\mathrm{cm})$ was measured.

- Seed weight was determined by weighting sample of 10 seed, seeds weight/ fruit weight ratio was also calculated. 


\section{Chemical fruit characters}

- Total Soluble Solids (TSS): were measured by hand refractometer in pulp juice.

- Acidity was determined as citric acid (\%) in juice.

- Fruit juice $\mathrm{pH}$ was determined by $\mathrm{pH}$ meter.

- Ascorbic acid fruit content (V.C) was measured in juice $(\mathrm{mg} / 100 \mathrm{~g})$ by titration with 2,6 Di-chlorophenol indophenol according to A.O.A.C. (1980).

- Fruit content of sugars was determined, the flesh of each fruit sample was cut into small pieces by a clean knife and mixed well. Five grams of the cut flesh were used for water extraction by distilled water according to A.O.A.C. (1980). The total sugars were determined colorimetically using phenol and sulphoric acid according to Malik and Singh (1980). The reducing sugars were determined by the Nelson arsenate-molybdate colorimetric method according to Dubios et. al. (1956). The non-reducing sugars were calculated by the difference between total sugars and reducing sugars.

- Fruit pigments: chlorophyll a, b, total chlorophyll and carotene $(\mathrm{mg} / 100 \mathrm{~g})$ were determined in skin according to Wensttein (1957).

\section{5- Leaf chlorophyll}

The average of 10 reading was taken during October on the leaves of the middle of the shoots from allover the tree circumference to determine the total chlorophyll content as SPAD unit using non destructive chlorophyll meter according to Monje and Bugbee (1992).

\section{6- Leaves and fruits mineral content}

In both studied seasons, ten leaves, during October, were selected for each tree under study to determine the leaf mineral content. In addition, during December for each season, ten fruits were taken from each tree under study to determine the fruit mineral content. The dried leaves and fruits samples were digested by sulphoric acid and hydrogen peroxide according to Evenhuis and Dewaard (1980). In this digested, solution nitrogen, phosphorus, potassium, calcium, magnesium, sodium, iron, manganese, copper and zinc were determined. Total nitrogen and phosphorous were determined by using Spectophotometer. Calcium and magnesium were determined by versenate (EDTA) method according to Cheng and Bray (1951). Potassium and sodium were measured against a standard using Flamephotometer. Iron, manganese, copper and zinc were determined by Perkin Elmer Atomic Absorpation Spectophotometer. Nitrogen, phosphorous, potassium, calcium, magnesium and sodium were expressed as a percentage (\%) on dry weight basis, while, iron, manganese, copper and zinc were expressed as part per of million (ppm). 


\section{7- Electrophoretic analysis}

Young fresh leaf samples of two Ziziphus mauritiana (Balahy and Tofahy) varieties were kindly supplied to the Horticulture Research Institute, Agricultural Research Center, Giza. Egypt. Samples from the experimental trees were gathered separately from each variety and treated for both SDS-protein and isozymes extraction.

\section{A- SDS-protein electrophoresis}

About $0.2 \mathrm{~g}$ of the plant materials was homogenized separately in $200 \mu \mathrm{l}$ buffer containing $1 \mathrm{M}$ Tris- $\mathrm{HCl}$ pH 8.8 and $0.25 \mathrm{M}$ EDTA. After centrifugation at 10.000 rpm for 10 minutes, $100 \mu$ supernatant containing water soluble protein were transferred to a new Eppendorf tube and mixed with $800 \mu \mathrm{l}$ acetone and then kept in a freezer for 15 minutes. After centrifugation at $10.000 \mathrm{rpm}$ for 10 minutes, the pellets were re-suspended in $80 \mu$ buffer containing $1 \mathrm{M}$ Tris- $\mathrm{HCl} \mathrm{pH} \mathrm{8.8,0.25} \mathrm{M}$ EDTA, $10 \%$ SDS and $10 \%$ glycerol. Mercaptoethanol was added to each tube and boiled in water bath for 10 minutes, SDS- polyacrylamide gel electrophoresis was performed $12.5 \%$ acrylamide slab gels following the system of Laemmli (1970). Electrophoresis was run at a current of $15 \mathrm{~mA}$ for 30 minutes followed by $25 \mathrm{~mA}$ till the tracing bromophenol blue dye reached the gel bottom. Molecular weights of different bands were calibrated with the following protein subunits as molecular weights standard: Isozyme (14.3 kDa), bovine serum albumin (66.2 KDa), trypsin in hibitor (21.5 kDa), carbonic anhydrase (30.0 kDa), ovalbumin(46.2 kDa), and phosphorylase b (97.4 kDa)

\section{B- Isozymes electrophoresis}

Isozyme extraction from the different treated trees of Ziziphus mauritiana varieties was performed separately for each variety and treated by homogenizing 0.5 $\mathrm{g}$ fresh leaf samples in $1 \mathrm{ml}$ extraction buffer using a mortar and pestle. The extract was then transferred into clean Eppendorf tubes and centrifuged at $10000 \mathrm{rpm}$ for 5 minutes. The supernatant was transferred to new clean Eppendorf tubes and kept at $20^{\circ} \mathrm{C}$ until using electrophoretic analysis.Vertical slab gel electrophoresis apparatus was used according to Stegemann et. al. (1985). A volume of $40 \mu \mathrm{l}$ extract each sample was mixed with $20 \mu$ sucrose and $10 \mu$ bromophenol blue, then a volume of $50 \mu \mathrm{l}$ from this mixture was applied to each well. The run was performed at 30 volt until the bromophenol blue dye has reached the separating gel and then the voltage was increased to 70 volt. After electrophoresis, the gels were stained according to their enzyme system with the appropriate substrate and chemical solutions then incubated at room temperature in the dark for complete staining. In most cases 
incubation for about 1 to 2 hours was enough. Staining of the gels for esterase (Est) was performed as described by Scandalios (1964). The gel was soaked in $0.5 \mathrm{~m}$ borate buffer $(\mathrm{pH} 4.1)$ for 90 minutes at $4^{\circ} \mathrm{C}$. The gel was stained for esterase activity by incubation at $37^{\circ} \mathrm{C}$ in a solution of $100 \mathrm{mg}$ a-naphthyl acetate (as a substrate) and $100 \mathrm{mg}$ fast blue RR salt in $200 \mathrm{ml}$ of $0.1 \mathrm{M}$ phosphate buffer $\mathrm{pH} 6.5$. While staining of the gels for peroxidase (Px) was performed as described by Larsen and Benson (1970). The staining solution was composed of $50 \mathrm{ml}$ of $1 \mathrm{M} \mathrm{Na}$ acetate, $\mathrm{pH} 4.7$, (TMBZ) and $2 \mathrm{ml}$ of $30 \% \mathrm{H}_{2} \mathrm{O}_{2}$.

\section{C- Randomly amplified polymorphic DNA (RAPD)}

In this study, RAPD was used for the identification of the two Indian jujube varieties according to Lu et. al. (1996) DNA extraction following the Dellaporta method (Dellaporta et. al., 1983) as follows:

About $0.1 \mathrm{gm}$ (fresh weight) of young leaves was ground to fine powder in liquid $\mathrm{N}_{2}$ in a mortar. Before the tissue thawed, $1 \mathrm{ml}$ extraction buffer $(100 \mathrm{mM}$ Tris$\mathrm{HCl} \mathrm{pH} \mathrm{8.0,50} \mathrm{mM} \mathrm{EDTA} \mathrm{and} 0.5 \mathrm{M} \mathrm{NaCl}$ ) and $0.2 \mathrm{ml} 20 \%$ SDS were added. The mixture was incubated at $65^{\circ} \mathrm{C}$ in water bath for 20 minutes. Then $1 \mathrm{ml}$ of phenol, chloroform and isoamyl alcohol (25:24:1) was added. Centrifugation was performed at $10000 \mathrm{rpm}$ for 10 minutes. The supernatants of each sample were transferred separately to a new tubes, then $1 \mathrm{ml}$ of chloroform and isoamyl (24:1) was added. Centrifugation was performed at $10000 \mathrm{rpm}$ for 10 minutes. The supernatants of each sample were transferred separately to a new tube, then $1 \mathrm{ml}$ of isopropanol was added and kept overnight in freezer. Centrifugation was formed at $10000 \mathrm{rpm}$ for 10 minutes. The resulted pellets containing DNA were re-suspended in $1 \mathrm{ml}$ ethanol. Centrifugation was performed at $10000 \mathrm{rpm}$ for 2 minutes. The DNA pellets were resuspended in $200 \mathrm{ml}$ TE (10 mM Tris- $\mathrm{HCl} \mathrm{pH} 8.0$ and $1 \mathrm{mM}$ EDTA) buffer. DNA was quantitated by spectrophotometer and gel electrophoresis.

A total of fifteen 10-mer random DNA oligonucleotide primers were independently used in the PCR reactions according to Williams et. al. (1990). The primers are from operon kit (Operon Tech. Inc., USA). Only five primers were generated reproducible polymorphism in the DNA profiles. Each experiment was repeated two times and only stable products were scored. The following are the code and sequences of these primers.

\begin{tabular}{|llllll|}
\hline No & Name & Nucleotide Sequence & No & Name & Nucleotide Sequence \\
\hline 1 & OP-A03 & $5^{\prime}$ CTGCTGGGAC 3' & 4 & OP-B03 & $5^{`}$ ACCGCGAAGC 3` \\
2 & OP-A05 & $5^{\prime}$ TCGGCCATAG 3` & 5 & OP-B05 & $5^{`}$ GGACCCAACC 3` \\
3 & OP-B01 & $5^{`}$ CTCACCGTCC 3` & & & \\
\hline
\end{tabular}




\section{Amplification was performed in $25 \mathrm{ml}$ reaction volume containing the following}

\begin{tabular}{|ll|}
\hline Primer & $2.5 \mu \mathrm{l}$ \\
Template DNA & $2.3 \mu \mathrm{l}$ \\
Sterile water & $7.7 \mu \mathrm{l}$ \\
2 X Ready mix RED Teq PCR & $12.5 \mu \mathrm{l}$ \\
\hline
\end{tabular}

\section{Reaction mix. It consists of the following}

- $20 \mathrm{mM}$ Tris- $\mathrm{HCl}(\mathrm{pH} 8.3)$

- $100 \mathrm{mM} \mathrm{KCl}$.

- $3 \mathrm{mM} \mathrm{MgCl}$.

- $0.002 \%$ gelatin

- $0.4 \mathrm{mM}$ dNTBs mix (dATP, dCTP, dGTP and dTTP).

- Stabilizers.

- 60 units Taq DNA polymerase/ml.

Each of the reaction mixtures was overlaid with a drop of light mineral oil per sample. Amplification was carried out in Perkin Elmer Gene Amp PCR thermocycler. The optimal conditions for PCR amplification was as follows: an initial 4 minutes denaturation step at $95^{\circ} \mathrm{C}$ followed by 35 cycles of 45 seconds at $94^{\circ} \mathrm{C}$. 1 minute at $37^{\circ} \mathrm{C}$ and 2 minutes at $72^{\circ} \mathrm{C}$, with a final extension step at $72^{\circ} \mathrm{C}$ for 12 minutes. A volume of $10 \mu \mathrm{l}$ of the RAPD products were electrophoresed in $1.4 \%$ agarose gel. The gel was prepared by adding $1.4 \mathrm{~g}$ agarose to $100 \mathrm{ml}$ of $1 \mathrm{X}$ TBE $(0.04 \mathrm{M}$ Trisaceate, $1 \mathrm{mM}$ EDTA, pH 8), followed by boiling in water bath. Then $0.5 \mu \mathrm{g} / \mathrm{ml}$ ethidium bromide was added to the melted gel. The melted gel was poured in the try of mini-gel apparatus and the comb was inserted immediately. The comb was removed when the gel became hardened. The electrophoresis buffer $(1 \mathrm{XTBE})$ was covered by the gel. About $10 \mu \mathrm{l}$ of DNA amplified product was loaded in each well and run at $60 \mathrm{~V}$ for about $45-75$ minutes. The gels were visualized and photographed by gel documentation system (Gel Doc Bio Rad 2000) under UV transilluminator.

\section{RESULTS AND DISCUSSION}

\section{1- Vegetative growth characters}

\section{a- The tree height}

The trees of Indian jujube were vigorous growing and had a wide spreading crown and a short bole. The results (Table 1 ) showed significant differences between the two varieties in both experimental seasons concerning tree height. Tofahy variety 
was higher than that of Balahy variety by $8.13 \%$ and $9.57 \%$ in both seasons, respectively. These results were in agreement with Griffiths (1990), who reported that the tree height was 2-5 to $15 \mathrm{~m}$.

\section{b- Leaf characters}

The leaf shape varied between varieties (figs. $1 \& 2$ ), as in Balahy variety, the leaves were oblong with dark green in the upper surface and hairy yellowish green in the under surface with 3 conspicuous, while in the Tofahy variety the leaves were oval with light green in the upper surface and hairy yellowish green in the under surface with 3 conspicuous. These results were in line with those found by Griffiths (1990), who reported that the leaves were alternate, distichous, elliptical, entire, or slightly toothed, distinctly-green and glabrous on the upper surface but cottony and pubescent on the under surface.

Data in Table (1) showed that there were, significant differences in leaf area, leaf length and leaf width among the two studied ber varieties. Tofahy variety was higher than Balahy variety in leaf area with $20.43 \%$ and $20.99 \%$, leaf length with $11.48 \%$ and $10.99 \%$ and leaf width with $10.73 \%$ and $15.85 \%$ in both seasons, respectively. These results were in line with Morton (1987), who reported that, the leaf length of Indian jujube was 2.5 to $6.25 \mathrm{~cm}$ and leaf width $2-4 \mathrm{~cm}$. Moreover, Saran et al. (2007) reported that the maximum value of leaf area in Indian jujube genotypes was $45.72 \mathrm{~cm}^{2}$. As for leaf length/width ratio, data in Table (1) indicated that, leaf length/width ratio of Balahy variety was more than Tofahy variety by 21.37 $\%$ in the second season. No significant differences between the two varieties in the first year of study were found.

\section{C- Shoot characters}

Ber shoots were pruned at the end of February or the beginning of March every year after harvesting. At the end of March, 1-10 shoots were developed on primary woody branches which bear leaves and flowers. These shoots take the shape of light zig-zag (Fig. 3). The shoots were selender, downy, bearing, paired of brown spines at the axils of the alternate leaves. One of the spines was straight and the other slightly hooked (Fig 7). The differences between both varieties in the shoots shape were not obvious.

Data in Table (1) revealed that the lengths of primary and secondary shoots of Tofahy variety were higher than Balahy variety. They were $13.49 \%$ and $10.17 \%$ for the length of primary shoots and by $11.18 \%$ and $5.28 \%$ for the length of secondary shoots in both seasons, respectively. 


\section{2- Flower morphology}

The flowers of Indian jujube were small and yellowish green containing 5 petalled as shown in Figures ( 3 and 4 ) and they appeared in clusters in the leaf axils, each cluster contained 5-10 flowers. The period of flowering started in the first week of June and extended to the middle of September. These data were in line with Morton (1987) who reported that the 5-petalled flowers of Indian jujube were yellow, tiny, in 2 or 3 inches in the leaf axils. In addition Griffiths (1990) reported that the flowers arising in the leaf axils were small and greenish.

\section{3- Yield, fruit set and fruit drop}

The averages of fruit yield (Table 2 ) of Tofahy variety was significantly higher than Balahy variety by $24.8 \%$ and $20.6 \%$ in both seasons, respectively. Also, number of fruits/ tree (Table 1 ) of Tofahy was higher than Balahy variety by $15.5 \%$ at the first season while, the differences between both varieties were un significant at the second season. In addition, the average of fruit weight of Tofahy was more than Balahy variety by $11.8 \%$ and $18.7 \%$ at both seasons respectively. These results were in line with Obeed et al. (2008), who reported that the averages fruit weight of Tofahy variety were 31.72 and $31.32 \mathrm{gm}$ in both seasons, respectively. As for the fruit set percentage (Table 1) of Tofahy variety, it was significantly higher than Balahy variety by $3.16 \%$ in the second season while, the differences between the two varieties in the first season were not big enough to be significant. The fruit drop percentages of Balahy and Tofahy varieties were not big enough to be significant in both seasons.

\section{4- Fruit characters}

\section{A- Physical fruit characters}

The fruits are a drupe, varying from round to elongate and at size of plum (Figs. 5 \& 6). The flesh was white, crispy, juicy, acid, or sub acid to sweet somewhat, astringent. Fully ripe fruits were wrinkled, the flesh buff-colored. The fruit contained one central brown stone (Figs. $7 \& 8$ ).

Data presented in Table (1) showed that the averages of fruit length of Balahy were higher than Tofahy by $6.7 \%$ and $15.4 \%$ in both seasons, respectively while, the average of fruit width of Tofahy was more than Balahy by $7 \%$ in the second season and there were, not significant differences between both varieties in fruit width and fruit length/ width ratio in the first season. Fruit length/ width ratio was significantly higher in Balahy than Tofahy by $14 \%$ in the second season. These results were in agreement with Obeed et al. (2008), who reported that Komethery cultivar fruit was the tallest $(5.83$ and $5.87 \mathrm{~cm})$, while, Um-sulaem cv. exhibited shortest (3.31 and $3.19 \mathrm{~cm}$ ) and Peyuan cv. was intermediate. 
Data presented in Table (1) showed that fruit firmness of Balahy was higher than Tofahy variety by 16.06 and $12.63 \%$ while, fruit pulp thickness of Tofahy was higher than Balahy by $12.88 \%$ and $8.49 \%$ in both seasons, respectively. As for fruit volume, there were not significant differences between both varieties in both seasons. These results were in agreement with Obeed et al. (2008). They reported that Tofahy and Peyuan cvs. had significantly larger fruit volume than the other three cultivars (35.53 and $36.33 \mathrm{~cm}^{3}$ ), respectively. In addition, Ezhilarasi and Tamilmani (2009) reported that the fruit firmness of Indian jujube ranged from 3.5 to $12.5 \mathrm{~kg} / \mathrm{cm}^{2}$.

Data presented in Table (1) showed that seed weight and seed/fruit weight ratio of Balahy were higher than Tofahy variety by $12.25 \%$ and $13.60 \%$ for seed weights and by $18.94 \%$ and $29.43 \%$ for seed/ fruit weight ratios in both seasons, respectively. These results were in line with Obeed et al. (2008). They reported that the heaviest seed weight was collected from Tofahy cv. $(2.0 \mathrm{~g})$ while the lightest seed weight was in Pakstany cv. (0.72g).

\section{B- Chemical fruit contents}

The averages of fruit acidity (Table 2) in Tofahy was higher than Balahy variety by $31.6 \%$ in the first season while there were no significant differences between the two varieties in the second season. Also, there were no differences between both varieties in total soluble solids in the two experimental seasons. These results were in agreement with Obeed et. al. (2008). They reported that the fruit of Um-suleam cv. had high content of juice acidity percentage compared with the other cultivars. Also, it had the highest TSS percentage.

The averages of TSS/ acidity ratio (Table 2) of Balahy was more than in Tofahy variety by $33.83 \%$ in the first season, while in the second year of study differences between the two varieties were not big enough to be significant. This explain that, the sweet taste of Balahy variety refer to the highest value of TSS/ acidity more than Tofahy variety. The average of ascorbic acid (Table 2) in Tofahy were higher than in Balahy variety by $16.16 \%$ and $17.62 \%$ in both experimental seasons, respectively.

Data presented in Table (2) showed that there were no significant differences for reducing, non-reducing and total sugars between both varieties at both seasons. These results were in agreement with Ibrahim et. al. (2009). They reported that reducing sugars content ranged from 2.37 to $3.34 \%$ and non-reducing sugars content from 4.15 to $6.38 \%$ in both seasons, respectively. Also, there were no significant differences between the two varieties at fruit juice $\mathrm{pH}$ in both seasons. Ezhilarasi and Tamilmani (2009) reported that the pH gradually increased in peel and pulp of ber fruit. 


\section{5- Leaf and fruit pigments}

\section{A- Total leaf chlorophyll}

The average of total leaf chlorophyll content (Table 2) of Balahy variety was more than in Tofahy variety by $6 \%$ in the first year of study while there were no significant differences between both varieties in the second season.

\section{B- Fruit chlorophyll}

In both experimental seasons (Table 2), the differences between Balahy and Tofahy varieties were not big enough to be significant for fruit chlorophyll $A$ and $B$ while total fruit chlorophyll was significantly higher in Balahy variety than in Tofahy by $3.13 \%$ in the first year of study only. Ezhilarasi and Tamilmani (2009) reported that the means of chlorophyll A, B and total gradually decreased during the ripening in ber fruits.

\section{C- Fruit carotene}

Data in Table (2) showed that there were no significant differences between Balahy and Tofahy varieties in fruit carotene contents in both seasons.

\section{6- Leaf and fruit mineral content}

\section{A- Leaf mineral content}

\section{1- Macro elements}

The averages of leaf nitrogen, phosphorus, potassium, calcium and magnesium were significantly higher in Tofahy variety than Balahy at both seasons (Table 3). Tofahy variety was more than Balahy variety by 9.5 and $7.65 \%$ for nitrogen, 18.18 and $20.69 \%$ for phosphorous, 31.07 and $33.14 \%$ for calcium and 11.59 and $12.31 \%$ for magnesium in both seasons, respectively. These results were in agreement with Morton (1987) who reported that leaf phosphorous varied between $0.17-0.33 \%$, potassium was $0.47-1.57 \%$, calcium was $1.42-3.74 \%$ and magnesium was $0.46-0.83 \%$ while, there were no significant difference between both varieties in leaf sodium contents in both seasons.

\section{2- Micro elements}

The averages of leaf iron, copper, manganese and zinc were significantly higher in Tofahy variety than Balahy in both seasons (Table 3). Tofahy variety was more than Balahy by 8.65 and $11.79 \%$ for iron, 21.89 and $17.52 \%$ for copper, 16.26 and $13.74 \%$ for manganese and 13.64 and 21.71 for zinc in both seasons, respectively. These results were in agreement with Amer et al. (2010). They reported that the leaf iron of Indian ber were 347.33-439 ppm, leaf copper were 106 and 375 ppm for Balahy variety and 110-355.67 for Tofahy, leaf manganese were 95.67 and 106.67 ppm for Balahy and 100 and 103 ppm for Tofahy and leaf zinc were 51.33 and 
$86.67 \mathrm{ppm}$ for Balahy variety and 52.67 and $84.67 \mathrm{ppm}$ for Tofahy variety in both seasons, respectively.

\section{B- Fruit mineral content}

\section{1- Macro elements}

The averages of fruit nitrogen, phosphorous, magnesium and sodium were significantly higher in Tofahy variety than Balahy in both seasons (Table 3). Tofahy variety was more than Balahy by 4.26 and $3.64 \%$ for nitrogen, 5.94 and $4.10 \%$ for phosphorous, 11.97 and $8.85 \%$ for magnesium and 4.67 and $7.53 \%$ for sodium in both seasons, respectively. Also, fruit potassium content of Tofahy variety was higher than Balahy by $22.59 \%$ in the second season and fruit calcium content of Tofahy variety was higher than Balahy by $19.91 \%$ in the first season. No other significant differences were recorded. These results were partially in line with Youssef (2005) who reported that ber fruit potassium content was ranged from 122.75 and 145.39 $\mathrm{mg} / 100 \mathrm{~g}$ and fruit sodium content in ber was 132.72 to $152.14 \mathrm{mg} / 100 \mathrm{~g}$.

\section{2- Micro elements}

The averages of fruit iron, copper, manganese and zinc (Table3) were significantly higher in Tofahy variety than Balahy in the first season. Tofahy variety was more than Balahy by 15.52 and $20.12 \%$ for iron, $8.9 \%$ in the second season for copper, 8.94 and $21.9 \%$ for manganese and 8.82 and $8.79 \%$ for zinc in both seasons, respectively. These results were in agreement with Amer et. al. (2010). They reported that fruit iron contents of ber were 116.1 to 122.73 and 108.33 to 116.67 ppm for Tofahy and Balahy varieties in two seasons of study, respectively. Also, fruit copper contents were 5.55 to 6.66 and 4.67 to $5.33 \mathrm{ppm}$ for Tofahy and Balahy varieties in the two years of study, respectively. As for fruit manganese, they reported that, Tofahy variety had 10.00 to $20.44 \mathrm{ppm}$ and 14.44 to $18.33 \mathrm{ppm}$ for Balahy variety in both seasons, respectively and fruit zinc values were 44.43 to $66.65 \mathrm{ppm}$ for Tofahy variety while they were 44.43 to $61.1 \mathrm{ppm}$ for Balahy variety in two years of study, respectively.

\section{7- Electrophoretic analysis}

There is a complete lack of information on the extent of genetic diversity in ber. This is the first study to investigate the extent of genetic diversity of cultivated ber genotypes in Egypt.

\section{Identification of the studied varieties}

SDS-PAGE of leaves proteins, isozymes (peroxidase and estrase), randomly amplified polymorphic DNA using PCR (RAPD-PCR) were used to assess the genetic diversity of the two varieties under investigation. 


\section{A- Identification based on biochemical analysis}

Leaf proteins provide valuable evidence for taxonomic and evolutionary relationships of plant species (Yates et. al., 1990). It is worthy to note that, leaf protein profiles are often species-specific, highly stable and unlikely not to be influenced by environmental conditions and seasonal fluctuations.

\section{SDS-protein electrophoresis in leaves}

The electrophoretic banding patterns of proteins extracted from leaves of the two Indian jujube varieties were shown in Figure (11). Their densitometric analyses are illustrated in Table (4). The presence and absence of bands were assessed with (1) and (0), respectively. The results of leaves SDS-PAGE revealed a total number of seventeen bands with molecular weights (MW) ranging from about 120.0 to $11.0 \mathrm{kDa}$. The analysis of data showed 12 common bands (monomorphic), while the remaining five bands were polymorphic with $29.4 \%$ polymorphisms. In which two of them were positive variety-specific markers at 58.0 and $46.0 \mathrm{KDa}$, respectively for Tofahy variety and the other three bands were positive variety-specific markers at 38.0, 36.0 and $25.0 \mathrm{KDa}$, respectively for Balahy variety.

\section{B- Identification based on Isozymes banding patterns}

\section{Peroxidase banding patterns}

Table (5) and Figure (12) represent peroxidase electrophoretic banding patterns among examined fresh leaf samples of selected Indian jujube varieties. A total of one band was characterized for the studied cultivars, which was present in the two cultivars at relative mobility 0.85 with high density. These results were in agreement with Hassan et. al. (2002) who used isozymes to identify prunus cultivars. They indicated that most of cultivars could be differentiated and some cultivars gave identical patterns. They reported the importance of electrophoretic techniques separation of proteins and isozymes in elucidating biochemical genetic markers.

\section{C- Identification based on molecular analysis Identification based on RAPD}

In the present study, RAPD-PCR was used to analyze the genetic polymorphisms of the two studied Indian jujube varieties, and to assess their genetic relationships using similarity index and dendrogram tree.

Five arbitrary random primers were used to determine RAPD polymorphism of the two Indian jujube varieties. The resulted amplified fragments are shown in Table (11) and their densitometric analyses are illustrated in Figure (11). Banding patterns were scored as present (1) or absent (0). A total number of 72 fragments were visualized across the two investigated genotypes, Table (11). Primers produced band numbers ranging from 11 (primer OP-A03) to 20 (primer OP-B03) across species, 
Figures (13 and 16). Primer OP-A03 resulted in eleven bands with molecular sizes from 160 to $752 \mathrm{bp}$, Figure (13) and Table (6). One band was polymorphic (9.0 \%), in which was variety-specific marker at 710 bp which considered as positive marker for Balahy variety. Primer OP-A05 indicated the amplification of fifteen bands with molecular size range from $80-1220$ bp Figure (14) and Table (7), one band was polymorphic $(9.0 \%)$ in which was variety-specific marker at 420 bp which considered as positive marker for Tofahy variety. Primer OP-B01 indicated the amplification of fourteen bands with size range from $135-1140$ bp, Figure(16) and Table (8), three bands were polymorphic (21.4\%), in which were variety-specific marker at 812,727 and $600 \mathrm{bp}$, respectively. two of them were positive markers for Tofahy variety and the third band was positive for Balahy variety. Primer OP-B03 resulted in twenty DNA fragments ranging in 105-1055 bp, Figure (17) and Table (9), three bands were polymorphic (15.0\%), in which there was variety-specific marker at 700, 380 and 230 $\mathrm{bp}$, respectively which were positive specific markers for Tofahy variety. Primer OPB05 resulted in twelve DNA fragments ranging in 130-785 bp, Figure (15) and Table (10), one band was polymorphic (8.3\%), in which was positive variety-specific marker at 380 bp for Balahy variety.

Table 1. Vegetative growth, fruit set, fruit drop and physical character of Balahy and Tofahy ber varieties in 2007 and 2008 seasons.

\begin{tabular}{|l|c|c|c|c|}
\hline \multirow{2}{*}{ Characters } & \multicolumn{2}{|c|}{ Tofahy } & \multicolumn{2}{c|}{ Balahy } \\
\cline { 2 - 5 } & $\mathbf{2 0 0 7}$ & $\mathbf{2 0 0 8}$ & $\mathbf{2 0 0 7}$ & $\mathbf{2 0 0 8}$ \\
\hline Tree hight (cm) & $408.6 \mathrm{a}$ & $399.2 \mathrm{a}$ & $375.4 \mathrm{~b}$ & $361.0 \mathrm{~b}$ \\
\hline Leaf area $\left(\mathrm{cm}^{2}\right)$ & $37.56 \mathrm{a}$ & $38.48 \mathrm{a}$ & $29.92 \mathrm{~b}$ & $30.40 \mathrm{~b}$ \\
\hline Leaf length (L) (cm) & $8.67 \mathrm{a}$ & $8.55 \mathrm{a}$ & $7.68 \mathrm{~b}$ & $7.61 \mathrm{~b}$ \\
\hline Leaf width (w) (cm) & $5.30 \mathrm{a}$ & $5.78 \mathrm{a}$ & $4.73 \mathrm{~b}$ & $4.86 \mathrm{~b}$ \\
\hline Leaf L/W ratio & $0.99 \mathrm{~b}$ & $0.92 \mathrm{~b}$ & $1.07 \mathrm{a}$ & $1.17 \mathrm{a}$ \\
\hline Length of primary shoots (cm) & $243.40 \mathrm{a}$ & $231.30 \mathrm{a}$ & $210.50 \mathrm{~b}$ & $207.80 \mathrm{~b}$ \\
\hline Length of secondary shoots (cm) & $90.80 \mathrm{a}$ & $90.80 \mathrm{a}$ & $82.60 \mathrm{~b}$ & $86.00 \mathrm{~b}$ \\
\hline No. of flowers & 4768 & 4726 & 4159 & 4312 \\
\hline Fruit set \% & $81.00 \mathrm{a}$ & $82.40 \mathrm{a}$ & $80.80 \mathrm{a}$ & $79.80 \mathrm{~b}$ \\
\hline Fruit drop \% & $14.60 \mathrm{a}$ & $13.00 \mathrm{a}$ & $15.80 \mathrm{a}$ & $16.20 \mathrm{a}$ \\
\hline No. of fruit/tree & $3382 \mathrm{a}$ & $3129 \mathrm{a}$ & $2857 \mathrm{~b}$ & $3078 \mathrm{a}$ \\
\hline Fruit weight (gm) & $31.40 \mathrm{a}$ & $31.50 \mathrm{a}$ & $27.70 \mathrm{~b}$ & $25.60 \mathrm{~b}$ \\
\hline Fruit length (L) & $4.20 \mathrm{~b}$ & $3.30 \mathrm{~b}$ & $4.50 \mathrm{a}$ & $3.90 \mathrm{a}$ \\
\hline Fruit width (w) & $4.20 \mathrm{a}$ & $3.60 \mathrm{a}$ & $4.20 \mathrm{a}$ & $3.30 \mathrm{~b}$ \\
\hline Fruit L/W ratio & $0.99 \mathrm{a}$ & $0.92 \mathrm{~b}$ & $1.07 \mathrm{a}$ & $1.17 \mathrm{a}$ \\
\hline Fruit volume (cm $\left.{ }^{3}\right)$ & $37.60 \mathrm{a}$ & $36.20 \mathrm{a}$ & $35.20 \mathrm{a}$ & $34.40 \mathrm{a}$ \\
\hline Fruit firmness & $13.22 \mathrm{~b}$ & $13.01 \mathrm{~b}$ & $15.75 \mathrm{a}$ & $14.89 \mathrm{a}$ \\
\hline Fruit pulp thickness (cm) & $1.50 \mathrm{a}$ & $1.40 \mathrm{a}$ & $1.30 \mathrm{~b}$ & $1.20 \mathrm{~b}$ \\
\hline Seed weight (gm) & $1.27 \mathrm{~b}$ & $1.28 \mathrm{~b}$ & $1.45 \mathrm{a}$ & $1.48 \mathrm{a}$ \\
\hline Seed/fruit weight ratio & $4.24 \mathrm{~b}$ & $4.07 \mathrm{~b}$ & $5.24 \mathrm{a}$ & $5.77 \mathrm{a}$ \\
\hline
\end{tabular}

* Similar letters for each character in the same season are not significantly different 
Table 2. Yield, leaf and fruit pigments and chemical properties of Tofahy and Balahy varieties in 2007 and 2008 seasons.

\begin{tabular}{|l|c|c|c|c|}
\hline \multirow{2}{*}{ Characters } & \multicolumn{2}{c|}{ Tofahy } & \multicolumn{2}{c|}{ Balahy } \\
\cline { 2 - 5 } & $\mathbf{2 0 0 7}$ & $\mathbf{2 0 0 8}$ & $\mathbf{2 0 0 7}$ & $\mathbf{2 0 0 8}$ \\
\hline Yield (kg) & $105.00 \mathrm{a}$ & $97.00 \mathrm{a}$ & $78.80 \mathrm{~b}$ & $77.30 \mathrm{~b}$ \\
\hline Acidity (\%) & $0.23 \mathrm{a}$ & $0.27 \mathrm{a}$ & $0.15 \mathrm{~b}$ & $0.18 \mathrm{a}$ \\
\hline TSS (\%) & $14.12 \mathrm{a}$ & $14.29 \mathrm{a}$ & $14.09 \mathrm{a}$ & $14.02 \mathrm{a}$ \\
\hline TSS/ Acidity ratio & $64.26 \mathrm{~b}$ & $56.39 \mathrm{a}$ & $97.12 \mathrm{a}$ & $87.38 \mathrm{a}$ \\
\hline Ascorbic acid (mg/100g) & $79.20 \mathrm{a}$ & $80.60 \mathrm{a}$ & $66.40 \mathrm{~b}$ & $64.50 \mathrm{~b}$ \\
\hline pH & $4.39 \mathrm{a}$ & $4.56 \mathrm{a}$ & $4.72 \mathrm{a}$ & $4.57 \mathrm{a}$ \\
\hline Total sugars (\%) & $11.74 \mathrm{a}$ & $12.25 \mathrm{a}$ & $12.86 \mathrm{a}$ & $12.52 \mathrm{a}$ \\
\hline Reducing sugars (\%) & $7.27 \mathrm{a}$ & $7.99 \mathrm{a}$ & $8.14 \mathrm{a}$ & $7.37 \mathrm{a}$ \\
\hline Non-reducing sugars (\%) & $4.47 \mathrm{a}$ & $4.52 \mathrm{a}$ & $4.72 \mathrm{a}$ & $4.90 \mathrm{a}$ \\
\hline Leaf total chlorophyll content (SPAD unit) & $41.80 \mathrm{~b}$ & $43.31 \mathrm{a}$ & $44.47 \mathrm{a}$ & $44.71 \mathrm{a}$ \\
\hline Fruit chlorophyllA content (mg/100g) & $6.57 \mathrm{a}$ & $6.60 \mathrm{a}$ & $6.43 \mathrm{a}$ & $6.51 \mathrm{a}$ \\
\hline Fruit chlorophyll B content (mg/100g) & $3.29 \mathrm{a}$ & $3.72 \mathrm{a}$ & $2.29 \mathrm{a}$ & $2.84 \mathrm{a}$ \\
\hline Fruit total chlorophyll content (mg/100g) & $41.80 \mathrm{~b}$ & $43.31 \mathrm{a}$ & $44.47 \mathrm{a}$ & $44.71 \mathrm{a}$ \\
\hline Fruit carotene content (mg/100g) & $3.45 \mathrm{a}$ & $4.42 \mathrm{a}$ & $3.27 \mathrm{a}$ & $4.40 \mathrm{a}$ \\
\hline
\end{tabular}

* Similar letters for each character in the same season are not significantly different

Table 3. Leaf and fruit mineral content of Balahy and Tofahy varieties in 2007 and 2008 seasons.

\begin{tabular}{|l|c|c|c|c|}
\hline \multirow{2}{*}{ Characters } & \multicolumn{2}{|c|}{ Tofahy } & \multicolumn{2}{c|}{ Balahy } \\
\cline { 2 - 5 } & $\mathbf{2 0 0 7}$ & $\mathbf{2 0 0 8}$ & $\mathbf{2 0 0 7}$ & $\mathbf{2 0 0 8}$ \\
\hline Leaf N (\%) & $1.99 \mathrm{a}$ & $1.96 \mathrm{a}$ & $1.80 \mathrm{~b}$ & $1.81 \mathrm{~b}$ \\
\hline Leaf P (\%) & $0.33 \mathrm{a}$ & $0.29 \mathrm{a}$ & $0.27 \mathrm{~b}$ & $0.23 \mathrm{~b}$ \\
\hline Leaf K (\%) & $1.27 \mathrm{a}$ & $1.18 \mathrm{a}$ & $1.18 \mathrm{~b}$ & $1.04 \mathrm{~b}$ \\
\hline Leaf Ca (\%) & $3.54 \mathrm{a}$ & $3.53 \mathrm{a}$ & $2.44 \mathrm{~b}$ & $2.36 \mathrm{~b}$ \\
\hline Leaf Mg (\%) & $0.69 \mathrm{a}$ & $0.65 \mathrm{a}$ & $0.61 \mathrm{~b}$ & $0.57 \mathrm{~b}$ \\
\hline Leaf $\mathbf{~ N a ~ ( \% ) ~}$ & $0.04 \mathrm{a}$ & $0.04 \mathrm{a}$ & $0.03 \mathrm{a}$ & $0.03 \mathrm{a}$ \\
\hline Leaf Fe (ppm) & $451 \mathrm{a}$ & $424 \mathrm{a}$ & $412 \mathrm{~b}$ & $374 \mathrm{~b}$ \\
\hline Leaf Cu (ppm) & $338 \mathrm{a}$ & $314 \mathrm{a}$ & $264 \mathrm{~b}$ & $259 \mathrm{~b}$ \\
\hline Leaf Mn (ppm) & $109.41 \mathrm{a}$ & $113.82 \mathrm{a}$ & $91.62 \mathrm{~b}$ & $98.18 \mathrm{~b}$ \\
\hline Leaf Zn (ppm) & $79.20 \mathrm{a}$ & $79.00 \mathrm{a}$ & $68.40 \mathrm{~b}$ & $54.80 \mathrm{~b}$ \\
\hline Fruit N (\%) & $1.08 \mathrm{a}$ & $1.10 \mathrm{a}$ & $1.04 \mathrm{~b}$ & $1.06 \mathrm{~b}$ \\
\hline Fruit Ca (\%) & $2.48 \mathrm{a}$ & $2.26 \mathrm{a}$ & $1.82 \mathrm{~b}$ & $2.09 \mathrm{~b}$ \\
\hline Fruit Mg (\%) & $2.34 \mathrm{a}$ & $2.26 \mathrm{a}$ & $2.06 \mathrm{~b}$ & $2.06 \mathrm{~b}$ \\
\hline Fruit Na (\%) & $0.96 \mathrm{a}$ & $0.93 \mathrm{a}$ & $0.92 \mathrm{~b}$ & $0.86 \mathrm{~b}$ \\
\hline Fruit Fe (ppm) & $114.70 \mathrm{a}$ & $108.28 \mathrm{a}$ & $96.90 \mathrm{~b}$ & $88.16 \mathrm{~b}$ \\
\hline Fruit Cu (ppm) & $4.35 \mathrm{a}$ & $5.10 \mathrm{a}$ & $4.32 \mathrm{a}$ & $3.94 \mathrm{~b}$ \\
\hline Fruit Mn (ppm) & $16.78 \mathrm{a}$ & $16.21 \mathrm{a}$ & $15.28 \mathrm{~b}$ & $12.66 \mathrm{~b}$ \\
\hline Fruit Zn (ppm) & $51.15 \mathrm{a}$ & $49.95 \mathrm{a}$ & $46.64 \mathrm{~b}$ & $45.56 \mathrm{~b}$ \\
\hline
\end{tabular}

* Similar letters for each character in the same season are not significantly different 
1514 MORPHOLOGICAL, PHYSIOLOGICAL AND BIOCHEMICAL GENETIC STUDIES ON SOME INDIAN JUJUBE (ZIZIPHUS MAURITIANA LAMK.) VARIETIES GROWN AT EL NUBARIA

Table 4. Densitometric analysis for SDS leaf proteins of the two Indian jujube varieties.

\begin{tabular}{|c|c|c|c|}
\hline \multirow{2}{*}{$\begin{array}{c}\text { Band } \\
\text { No. }\end{array}$} & $\begin{array}{l}\text { MW } \\
\text { KDa }\end{array}$ & \multicolumn{2}{c|}{ Jujube varieties } \\
\cline { 3 - 4 } & 120.0 & 1 & Balahy \\
\hline 1 & 95.0 & 1 & 1 \\
\hline 2 & 72.0 & 1 & 1 \\
\hline 3 & 63.0 & 1 & 1 \\
\hline 4 & 58.0 & 1 & 0 \\
\hline 5 & 52.0 & 1 & 1 \\
\hline 6 & 46.0 & 0 & 1 \\
\hline 7 & 38.0 & 0 & 1 \\
\hline 8 & 36.0 & 1 & 1 \\
\hline 9 & 34.0 & 1 & 1 \\
\hline 10 & 32.0 & 1 & 1 \\
\hline 11 & 30.0 & 0 & 1 \\
\hline 12 & 25.0 & 1 & 1 \\
\hline 13 & 18.0 & 1 & 1 \\
\hline 14 & 16.0 & 1 & 1 \\
\hline 15 & 13.0 & 1 & 1 \\
\hline 16 & 11.0 & 15 & 15 \\
\hline 17 & & & \\
\hline
\end{tabular}

Table 5. Peroxidase isozyme banding patterns for the two Indian jujube varieties.

\begin{tabular}{|c|c|c|c|}
\hline \multirow{2}{*}{$\begin{array}{c}\text { Peroxidase } \\
\text { groups }\end{array}$} & \multirow{2}{*}{$\begin{array}{c}\text { Relative } \\
\text { mobility }\end{array}$} & \multicolumn{2}{|c|}{ Indian jujube varieties } \\
\cline { 3 - 4 } & 0.85 & ++ & Balahy \\
\hline Px1 & & ++ \\
\hline
\end{tabular}

Table 6. DNA polymorphism using randomly amplified polymorphic DNA (RAPD) for the two Indian jujube varieties with primers OP-A03.

\begin{tabular}{|c|c|c|c|}
\hline \multirow{2}{*}{ Band No. } & \multirow{2}{*}{$\begin{array}{l}\text { M.W } \\
\text { (bp) }\end{array}$} & Balahy & Tofahy \\
\cline { 3 - 4 } & 750 & 1 & 1 \\
\hline 1 & 710 & 0 & 1 \\
\hline 2 & 490 & 1 & 1 \\
\hline 3 & 375 & 1 & 1 \\
\hline 4 & 300 & 1 & 1 \\
\hline 5 & 275 & 1 & 1 \\
\hline 6 & 236 & 1 & 1 \\
\hline 7 & 220 & 1 & 1 \\
\hline 8 & 190 & 1 & 1 \\
\hline 9 & 175 & 1 & 1 \\
\hline 10 & 160 & 1 & 11 \\
\hline 11 & & 10 & \\
\hline
\end{tabular}


Table 7. DNA polymorphism using randomly amplified polymorphic DNA (RAPD) for the two Indian jujube varieties with primers OP-A05

\begin{tabular}{|c|c|c|c|}
\hline \multirow{2}{*}{ Band No. } & \multirow{2}{*}{$\begin{array}{l}\text { M.W } \\
\text { (bp) }\end{array}$} & \multicolumn{2}{|c|}{ Indian jujube varieties } \\
\hline & & Balahy & Tofahy \\
\hline 1 & 1220 & 1 & 1 \\
\hline 2 & 1080 & 1 & 1 \\
\hline 3 & 960 & 1 & 1 \\
\hline 4 & 825 & 1 & 1 \\
\hline 5 & 725 & 1 & 1 \\
\hline 6 & 550 & 1 & 1 \\
\hline 7 & 420 & 1 & 0 \\
\hline 8 & 390 & 1 & 1 \\
\hline 9 & 330 & 1 & 1 \\
\hline 10 & 300 & 1 & 1 \\
\hline 11 & 260 & 1 & 1 \\
\hline 12 & 210 & 1 & 1 \\
\hline 13 & 170 & 1 & 1 \\
\hline 14 & 120 & 1 & 1 \\
\hline 15 & 95 & 1 & 1 \\
\hline \multicolumn{2}{|c|}{ Total } & 15 & 14 \\
\hline
\end{tabular}

Table 8. DNA polymorphism using randomly amplified polymorphic DNA (RAPD) for the two Indian jujube varieties with primers OP-B01.

\begin{tabular}{|c|c|c|c|}
\hline \multirow{2}{*}{ Band No. } & \multirow{2}{*}{$\begin{array}{l}\text { M.W } \\
\text { (bp) }\end{array}$} & Balahy & Tofahy \\
\cline { 3 - 4 } & 1135 & 1 & 1 \\
\hline 1 & 1005 & 1 & 1 \\
\hline 2 & 890 & 1 & 1 \\
\hline 3 & 812 & 1 & 0 \\
\hline 4 & 727 & 1 & 0 \\
\hline 5 & 600 & 0 & 1 \\
\hline 6 & 575 & 1 & 1 \\
\hline 7 & 450 & 1 & 1 \\
\hline 8 & 405 & 1 & 1 \\
\hline 9 & 365 & 1 & 1 \\
\hline 10 & 320 & 1 & 1 \\
\hline 11 & 220 & 1 & 1 \\
\hline 12 & 180 & 1 & 1 \\
\hline 13 & 135 & 1 & 12 \\
\hline 14 & & 13 & \\
\hline
\end{tabular}


Table 9. DNA polymorphism using randomly amplified polymorphic DNA (RAPD) for the two Indian jujube varieties with primers OP-B03.

\begin{tabular}{|c|c|c|c|}
\hline \multirow{2}{*}{ Band No. } & \multirow{2}{*}{$\begin{array}{l}\text { M.W } \\
\text { (bp) }\end{array}$} & \multicolumn{2}{|c|}{ Indian jujube varieties } \\
\hline & & Balahy & Tofahy \\
\hline 1 & 1055 & 1 & 1 \\
\hline 2 & 965 & 1 & 1 \\
\hline 3 & 815 & 1 & 1 \\
\hline 4 & 765 & 1 & 1 \\
\hline 5 & 700 & 1 & 0 \\
\hline 6 & 605 & 1 & 1 \\
\hline 7 & 515 & 1 & 1 \\
\hline 8 & 490 & 1 & 1 \\
\hline 9 & 430 & 1 & 1 \\
\hline 10 & 380 & 1 & 0 \\
\hline 11 & 320 & 1 & 1 \\
\hline 12 & 260 & 1 & 1 \\
\hline 13 & 240 & 1 & 1 \\
\hline 14 & 230 & 1 & 0 \\
\hline 15 & 200 & 1 & 1 \\
\hline 16 & 160 & 1 & 1 \\
\hline 17 & 140 & 1 & 1 \\
\hline 18 & 128 & 1 & 1 \\
\hline 19 & 120 & 1 & 1 \\
\hline 20 & 105 & 1 & 1 \\
\hline \multicolumn{2}{|c|}{ Total } & 20 & 17 \\
\hline
\end{tabular}

Table 10. DNA polymorphism using randomly amplified polymorphic DNA (RAPD) for the two Indian jujube varieties with primers OP-B05.

\begin{tabular}{|c|c|c|c|}
\hline \multirow{2}{*}{ Band No. } & \multirow{2}{*}{$\begin{array}{l}\text { M.W } \\
\text { (bp) }\end{array}$} & Balahy & Tofahy \\
\cline { 3 - 4 } & 785 & 1 & 1 \\
\hline 1 & 700 & 1 & 1 \\
\hline 2 & 510 & 1 & 1 \\
\hline 3 & 470 & 1 & 1 \\
\hline 4 & 415 & 1 & 1 \\
\hline 5 & 380 & 0 & 1 \\
\hline 6 & 280 & 1 & 1 \\
\hline 7 & 265 & 1 & 1 \\
\hline 8 & 210 & 1 & 1 \\
\hline 9 & 155 & 1 & 1 \\
\hline 10 & 135 & 1 & 1 \\
\hline 11 & 130 & 1 & 12 \\
\hline 12 & & 11 & 1 \\
\hline
\end{tabular}


Table 11. Polymorphism detected for all systems used in Indian jujube varieties descrimination.

\begin{tabular}{|l|c|c|c|c|c|}
\hline \multicolumn{1}{|c|}{ System } & Polymorphic & Monomorphic & Unique & Total & $\begin{array}{c}\text { Polymorphism } \\
\%\end{array}$ \\
\hline Protein & 5 & 12 & 5 & 17 & $29.4 \%$ \\
\hline Isozymes & 0 & 1 & 0 & 1 & $0 \%$ \\
\hline RAPD & 9 & 63 & 9 & 72 & $12.5 \%$ \\
\hline Total & 14 & 76 & 14 & 90 & $15.5 \%$ \\
\hline
\end{tabular}
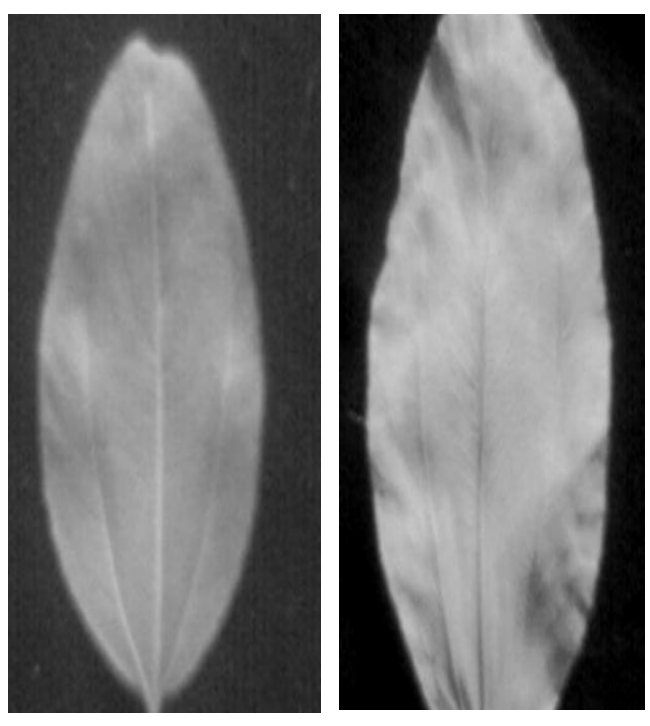

(1)

(2)

Fig.1. The leaves of Balahy variety

1: upper surface of Balahy leaf variety

2: lower surface of Balahy leaf variety
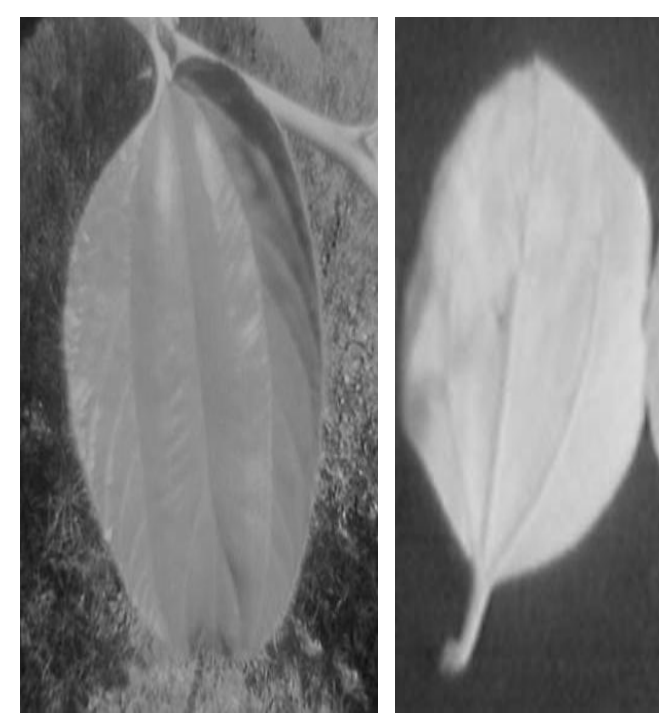

(3)
(4)
Fig. 2. The leaves of Tofahy variety

3: upper surface of Tofahy leaf variety

4: lower surface of Tofahy leaf variety 

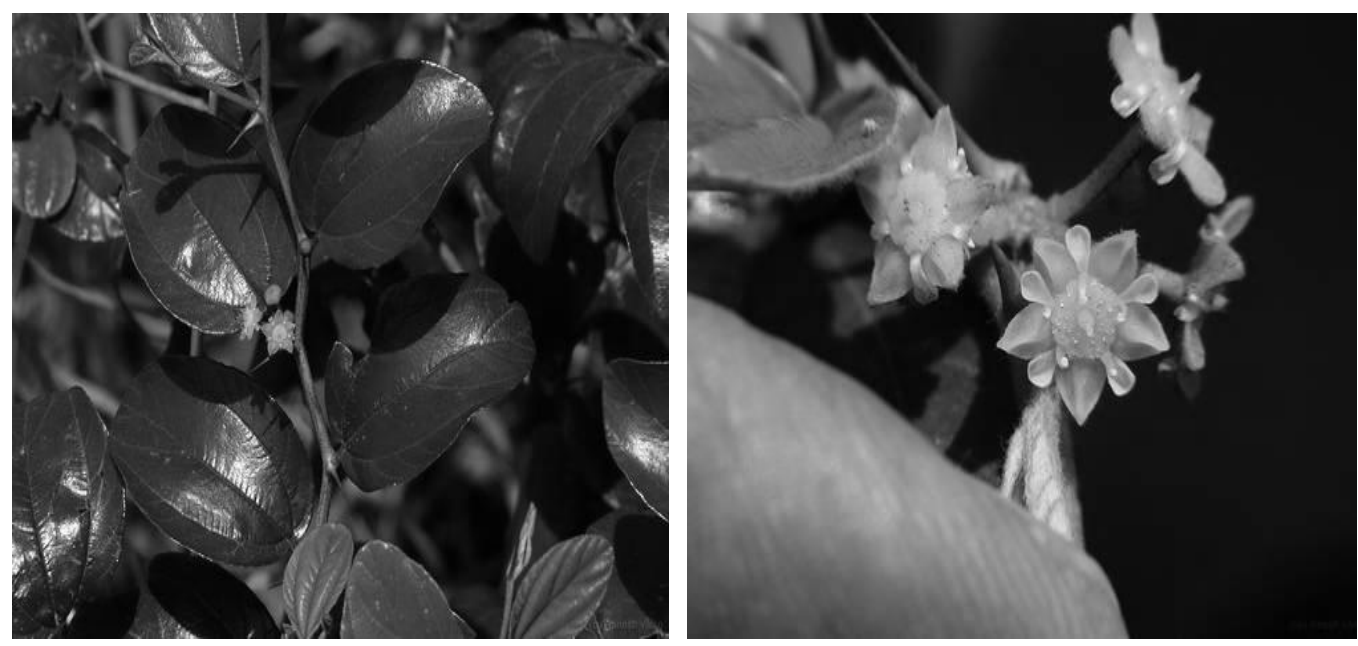

Fig. 3. The flowers of Balahy variety

Fig. 4. The flowers of Tofahy variety

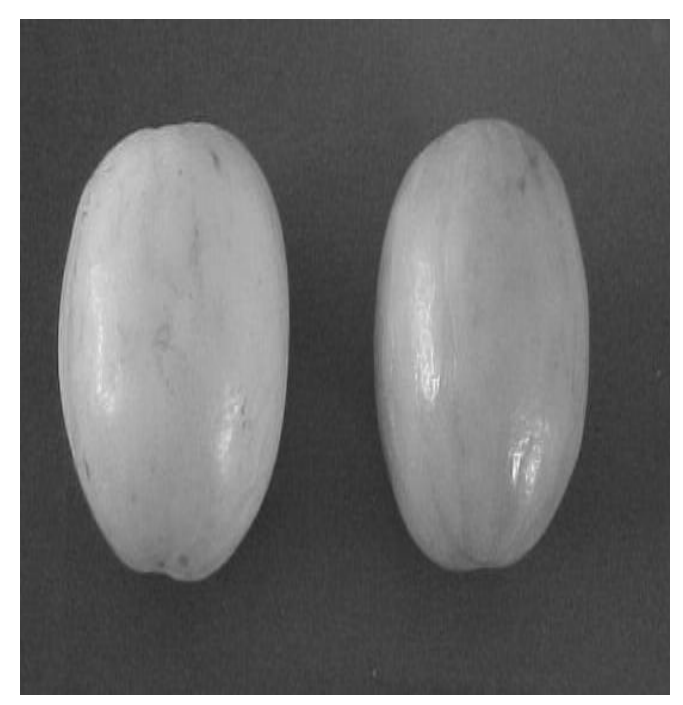

Fig. 5. The fruit shape of Balahy variety

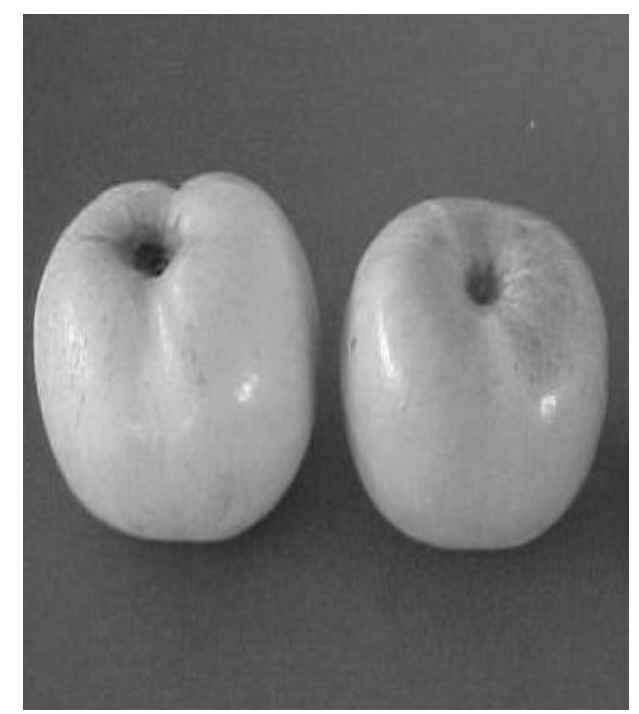

Fig. 6. The fruit shape of Tofahy variety 


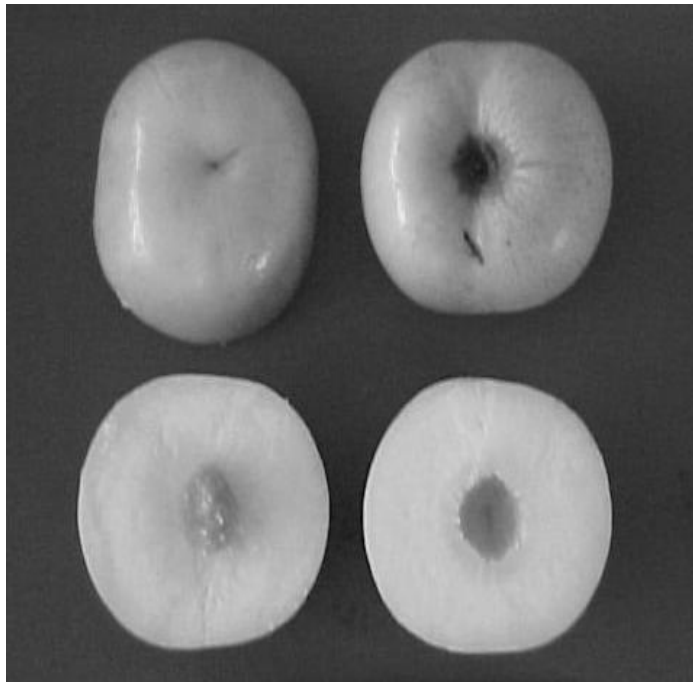

Fig. 7. Cross section in Tofahy fruit

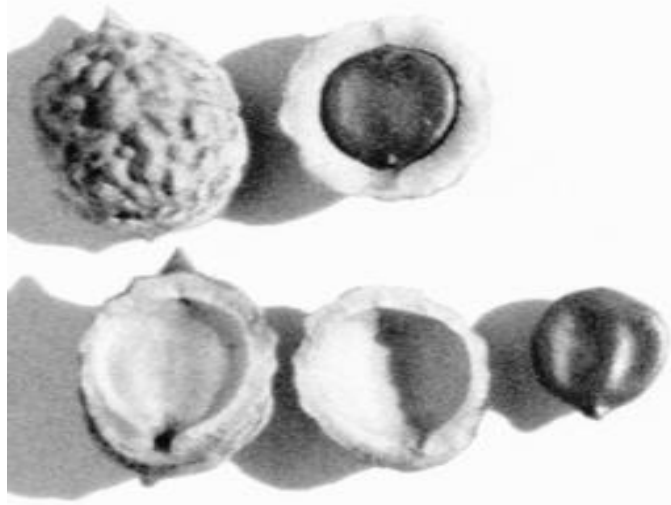

Fig. 9. The seeds of Tofahy variety

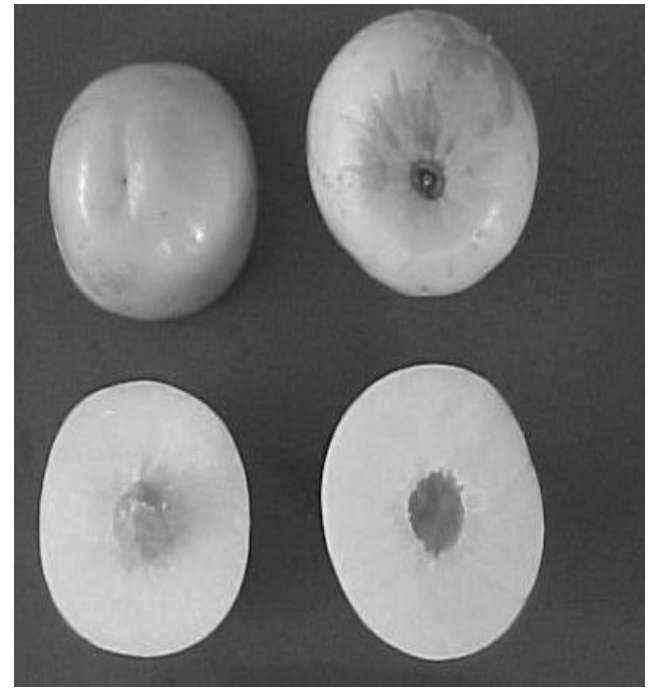

Fig. 8. Cross section in Balahy fruit

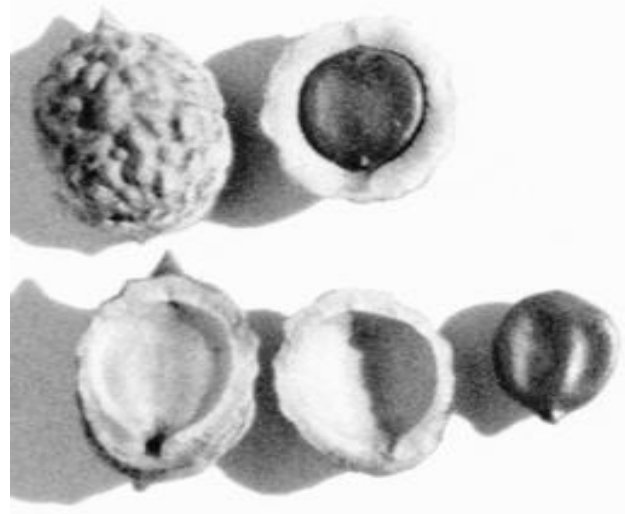

Fig. 10. The seeds of Balahy variety 


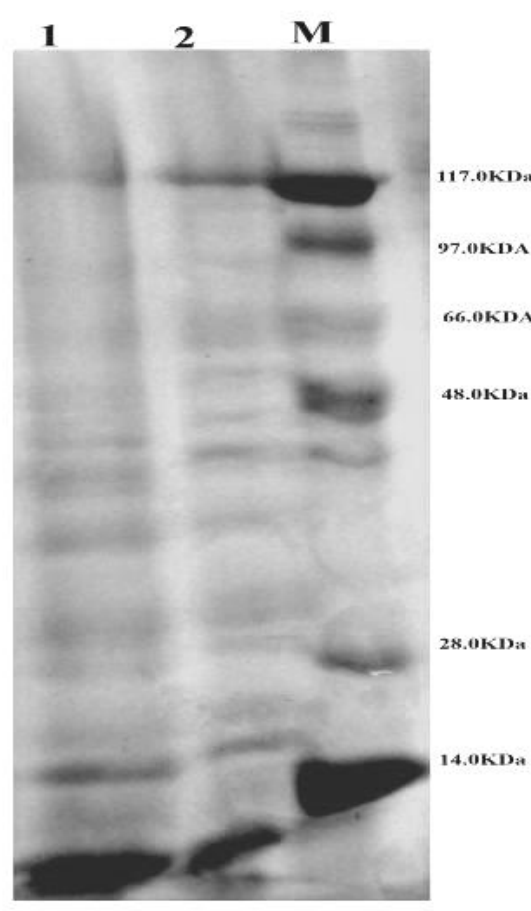

SDS-PAGE

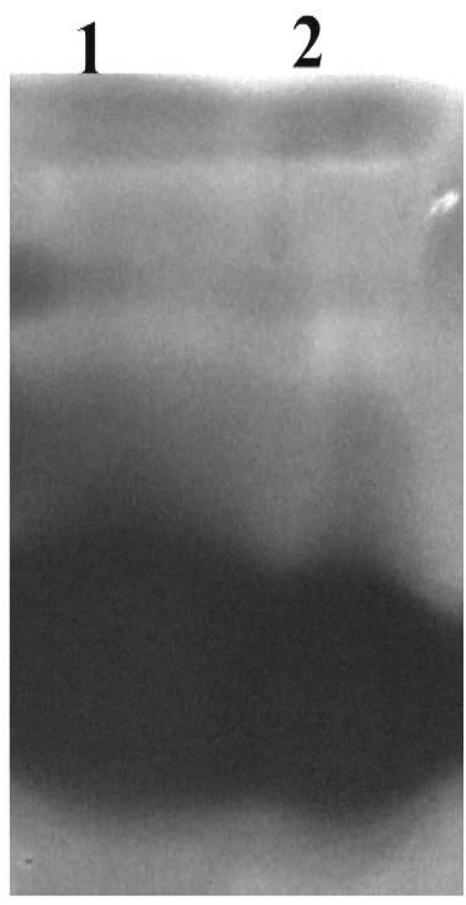

Fig. 12. Peroxidase isozyme banding patterns for the two Indian jujube varieties

1- Balahy variety

2- Tofahy variety 


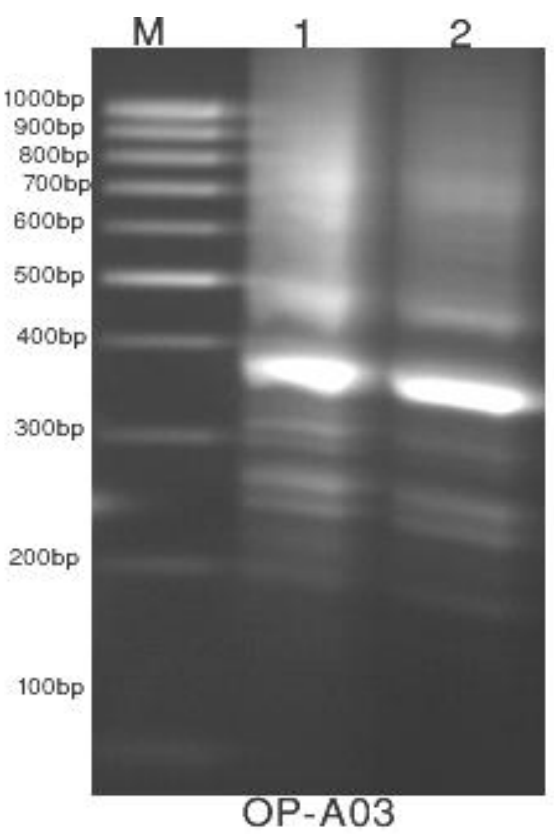

Fig. 13. DNA polymorphism of the two Indian jujube varieties amplified with primers OP-A03

1- Balahy variety

2- Tofahy variety

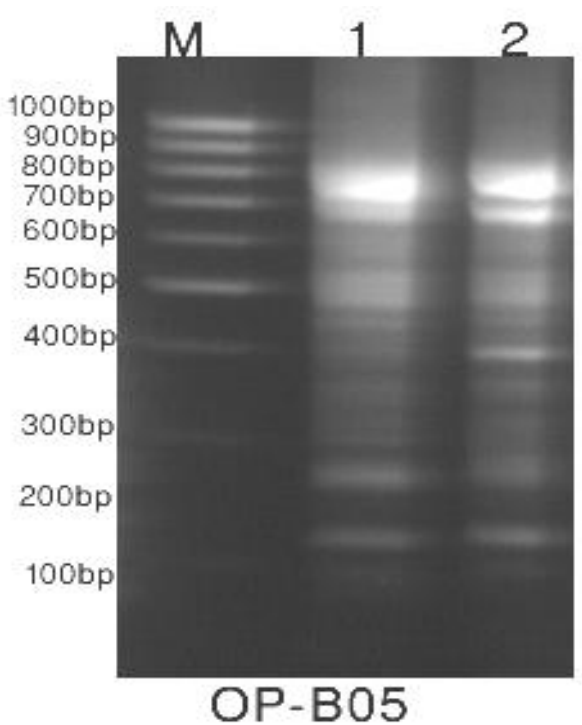

Fig 15. DNA polymorphism of the two Indian jujube varieties amplified with primers OP-B05

1- Balahy variety

2- Tofahy variety

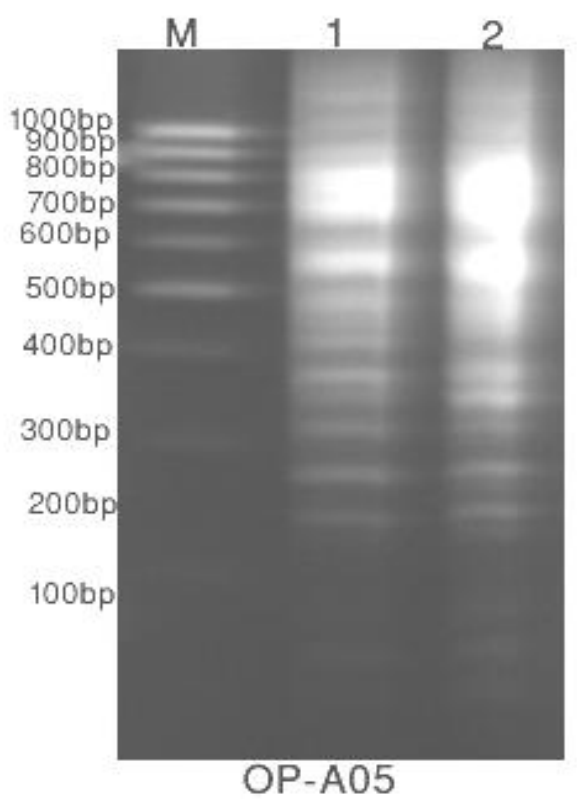

Fig. 14. DNA polymorphism of the two Indian jujube varieties amplified with primers OP-A05

1- Balahy variety

2- Tofahy variety

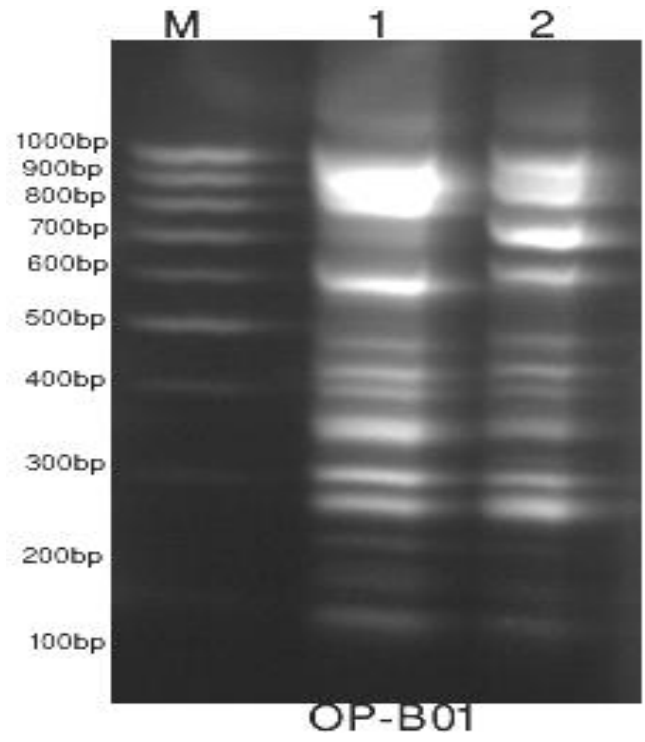

Fig. 16. DNA polymorphism of the two Indian jujube varieties amplified with primers OP-B01

1- Balahy variety

2- Tofahy variety 


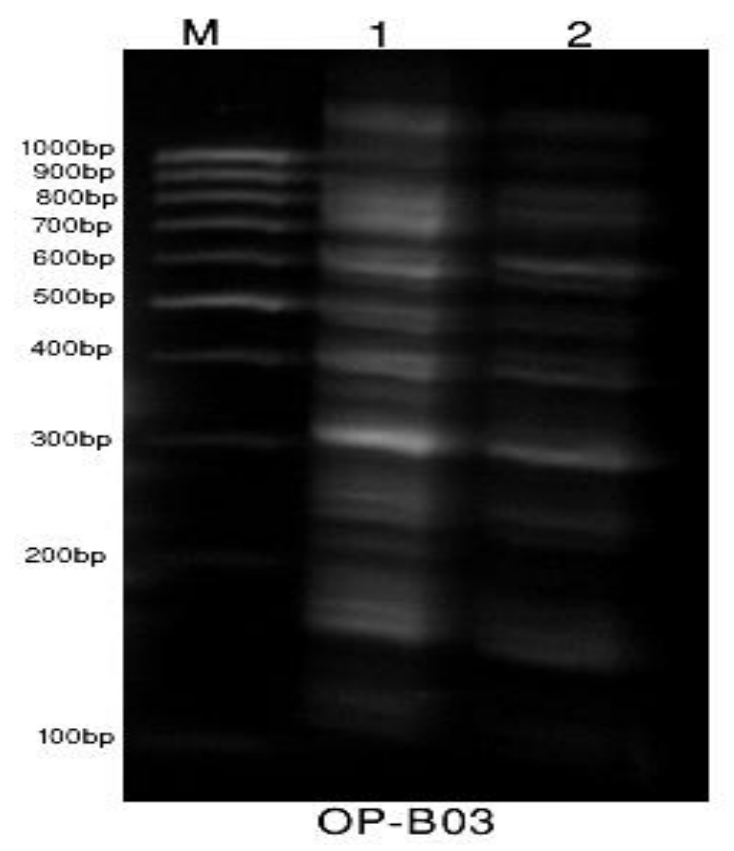

Fig. 17. DNA polymorphism of the two Indian jujube varieties amplified with primer OP-B03.

1- Balahy variety 2- Tofahy variety

\section{REFERENCES}

1. Amer, M. A., Afaf M. A. Y. and G. K. Adel. 2010. Effect of different levels of soil and foliar application of micro-nutrients fertilizer on Tofahy and Balahy Indian ber trees (Ziziphus mauritiana Lamk) grown in sandy soil. Alex. Sci. J. 31(1): 25-37.

2. A. O. A. C. 1980. Official methods of analysis, $13^{\text {th }}$ ed. Association of Official Analytical Chemistry, 28: 350-356.

3. Cheng, K. L. and R. H. Bray. 1951. Determination of calcium and magnesium in soil and plant material .Soil Sci., 72: 449- 458.

4. Delaporta, S. L., J. Wood and J. B. Hicks. 1983. Alpant DNA mini prepartation version III. Plant Mol. Biol., Rep.1: 19-21.

5. Dubios, M., K. A. Gilles, J. K. Hamilton, P. A. Rebers and F. Smith. 1956. Colorimetric method for determination of sugars and related substances. Analytical Chemistry, 28: $350-356$.

6. Evenhuis, B. and P. W. Dewaard. 1980. Principles and practices in plant analysis. FAO Soils Bull, 38 (1): 152-163. 
7. Ezhilarasi, E. and C. Tamilmani. 2009. Influence of pady hunk on the ripening of fruit of (Ziziphus mauritiana Lamk.). ARPN. J. Agric. and Biological Science, 4(6): $29-42$.

8. Griffiths, D. A. 1990. Ziziphus a tree crop for arid and semi-arid conditions. Wanatca Year Book, 15: 3-23.

9. Hassan, H. Z., M. M. Gad and S. L. Maximous. 2002. Geographical effects on the genetic fingerprint of populus species based on isozymes and DNA polymorphism. Egypt. J. Genet. Cytol., 31: 47- 66.

10. Ibrahim, M.M.Z., M. O. H. Shafique, M. M. Tahman, S. K. Biswas and M. S. Islam. 2009. Studies on the pyysiological and biochemical composition of different ber (Ziziphus mauritiana Lamk) cultivars at Rajshahi. Bngladesh, J. Sci. Ind. Res., 44(2): 229-232.

11. Laemmli U. K. 1970. Cleavage of structural proteins during assembly of head bacteriophage Tu. Nature, 227: 680-685.

12. Larsen, A. L. and W. C. Benson. 1970. Variety-specific variants of oxidative enzymes from soybean seeds. Crop Science, 10: 493-495.

13. Lu, Z. X., G. L. Reighard, W. V. Baird, A. G. Abbott and S. Rajapakse. 1996. Identification of Peach rootstock cultivars by RAPD markers. Hort. J. Sci. 31: 127129.

14. Malik, C. P. and M. B. Singh. 1980. Plant enzymology and histo- enzymology. A text Manual. Kalyani Publishers. New Delhi, India.

15. Monje, O. A. and B. Bugbee. 1992. Inherent limitation of nondestructive chlorophyll meters. A comparison of two types of meters. Hort. Sci., 27: 69-71.

16. Morton, J. 1987. Indian jujube (Zizuphus mouritiana Lam.). In: Fruits of Warm Climates, Morton, J. F. (Ed.). Mi-Ami, Florida, P: 272-275.

17. Ngwa, A. T. and J. M. Mafeni. 2000. Feed selection and dietary preferences of forage by small ruminants grazing natural pastures in the sahelian zone of Cameroon. Animal Feed Science and Technology, 88: 253- 266.

18. Obeed, R.S., M.M. Harhash and A. L. Abdel-Mawgood 2008. Fruit properties and genetic diversity of five Ber (Zizuphus mauritiana Lamk.) cultivars. Pakistan. J. Biol. Sci., 11(6): 888-893.

19. Pareek, O. P. 1983. The Ber. The Indian Council of Agricultural Research, New Delhi, PP: 1-80.

20. Saran, P. L., A. K. Godara and R. P. Dala. 2007. Biodiversity among Indian jujube (Zizuphus mouritiana Lamk.) genotypes for powdery mildew and other traits. Not. Bot. Hort. Agrobot. Cluj, 35(2): 15 - 21. 
21. Scandalios J. C. 1964. Tissue-specific isozyme variations in maize J. Hered. 55: 281-285.

22. Snedecor, G. W. and W. G. Cochran. 1980. Statistical methods. 6. ED. The Lowa St. Univ., Press Ames U.S.A.

23. Stegemann, H., A. M. R. Alifiy and K. R. F. Hussein. 1985. Cultivar indentification of dates (Phoenix dactylifera) by protein patterns. $2^{\text {nd }}$ International Symposium of Biochemical Approaches to Identification of cultivars. Braunschweig, west Germany, pp. 44.

24. Wensttein, D. V. 1957. Chorophyll letal and der supunikros Kapisene, jor winneck sec. Der. Platiden. Experimental Cell TEsearch, 12, 427.

25. Williams, J. G. K., A. R. Kubelik, K. J. Livak, J. A. Rafalski and S. V. Tingey. 1990. DNA polymorphisms amplified by arbitrary primers are useful as genetic markers. Nuclic Acid Res., 18: 6531-6535.

26. Yates, S. G., R. J. Petroski and R. G. Powell. 1990. Analysis of loline alkaloids in endophyte-infected tall fescue by capillary gas chromatography. J. Agric. Food. Chem., 38: 182-185.

27. Youssef, S. M. 2005. Evaluation of five varieties of jujube fruits for their processing suitability . Annals of Agric .Sc. Moshtohor, 43(2):687-697. 


\section{دراسات مورفولوجية وفسيولوجية وكيمو حيوية وراثية على بعض اصناف العناب \\ الهندى الناميه فى النوباريه}

ثناء مصطفى درويش عز 1 عفاف محمد على يوسف2 محد إبر اهيم حسن فرج2

$$
\begin{aligned}
& \text { ا ـ ـ قسم الإنتاج النباتى- كلية الزراعة- سابا باشا- جامعة الإسكندرية }
\end{aligned}
$$

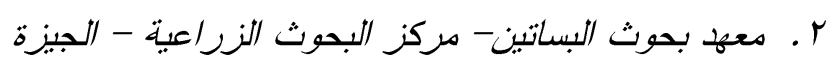

اجريت هذه الدراسه بمزرعه خاصده خلال عامى 2007 و 2008 لدر اسة الصفات

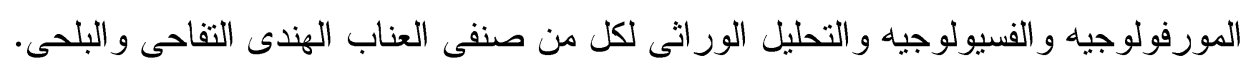

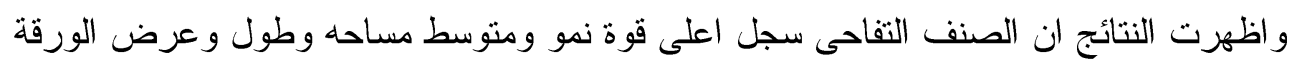

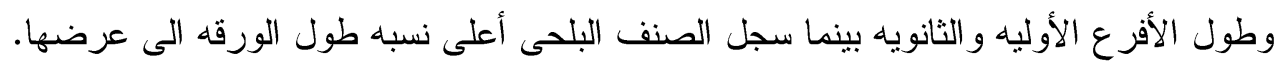

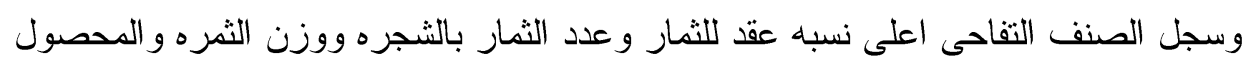

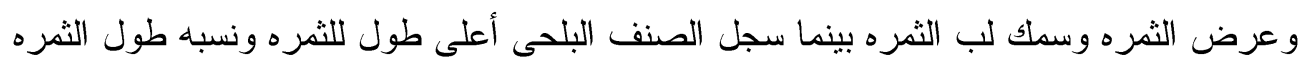

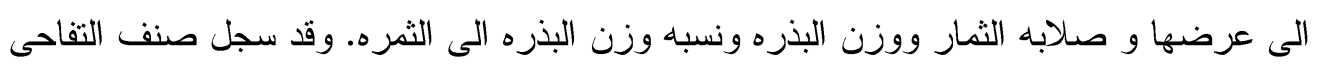

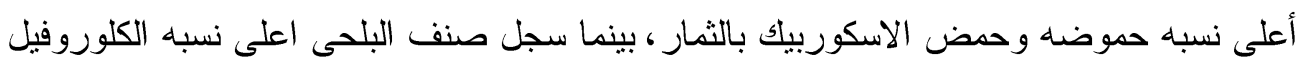

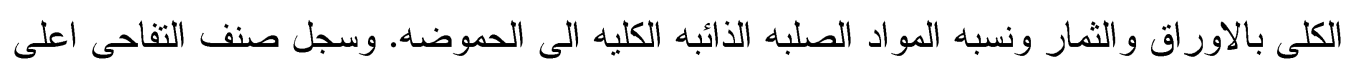

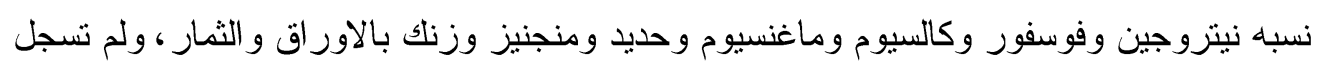

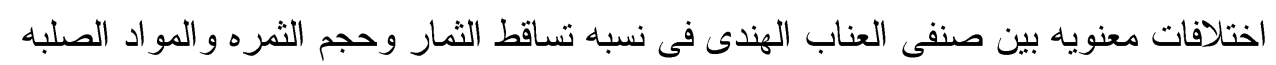

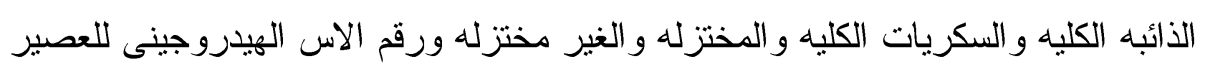

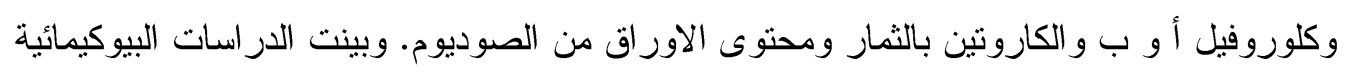

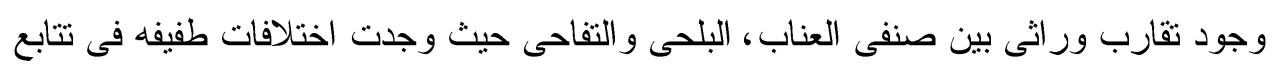
الاحماض الامينيه فى البروتينات و القو اعد النيتروجينيه. 